\title{
Cross-border acquisitions in the global food sector
}

\author{
Nils Herger
}

Department of Economics, University of Berne, Switzerland

\section{Christos Kotsogiannis and Steve McCorriston}

Department of Economics, University of Exeter, England, UK

Received August 2007; final version received October 2008*

\section{Summary}

Cross-border acquisitions constitute the main form of foreign direct investment in the world economy, the focus of this paper being to consider the determinants of the location and growth of cross-border acquisitions in the global food sector. The data relates to over 2,000 international acquisitions in the food sector from 45 source to 46 host countries. The results highlight the importance of market size, relative costs and stock market growth as important determinants. We also report differences involving acquisitions in food processing and retailing and higher and lower/middle income countries. Results involving acquisitions in European countries are also highlighted.

Keywords: foreign direct investment, cross-border acquisitions, count data, food sector

JEL classification: F23, G34, L66

\section{Introduction}

One of the main features of the process of globalisation in the past two decades has been the growth of foreign direct investment (FDI), which has far exceeded the growth of trade (Feenstra, 1998). While FDI may take alternative forms, cross-border mergers and acquisitions provide the main vehicle by means of which multinational firms access overseas markets. UNCTAD reports that in 2000 around 80 per cent of world FDI could be attributed to international merger and acquisition activity (UNCTAD, 2001) with the value of global acquisitions rising from US\$100 billion in 1987 to US\$720 billion in 1999. ${ }^{1}$ Annual average growth rates of cross-border acquisitions have been dramatic,

\footnotetext{
*Review coordinated by Thomas Heckelai.

1 In this paper (as in UNCTAD, 2001), the reference is to ownership and control and hence we set the definition of an acquisition to having at least 50 per cent ownership of the target firm. However, within this category, there are alternative characterisations of types of FDI that relate to different motives including horizontal, vertical and export platform FDI. We comment further on these distinctions below.
} 
increasing from an average annual rate of 26.4 per cent in the 1986-1990 period to an average annual growth rate of 47 per cent in the 1996-1999 period. Following a significant downturn in FDI between 2000 and 2004, the value of cross-border acquisitions recovered thereafter reaching US $\$ 380$ billion worldwide in 2005. Such is the prominence of cross-border acquisitions as the principal channel through which FDI occurs that more than 90 per cent of all FDI between developed countries takes this form. The role of acquisitions is slightly less when developing and transition countries are involved though, as UNCTAD notes, this has also been increasing in recent years with around 40 per cent of FDI inflows into developing and transition countries taking this form, up from 10 per cent in the late 1980s (UNCTAD, 2005).

Reflecting its growth and prominence worldwide, the data suggest that cross-border acquisitions in the global food sector have also increased substantially, from around US $\$ 4$ billion in 1987 to US $\$ 50$ billion in 2000. In terms of overall deal values of global acquisitions in the manufacturing sector over the period 1987-2000, the food industry ranked among the leading sectors. For example, in 1999 cross-border acquisitions in the food sector accounted for around 10 per cent of total activity in manufacturing worldwide while in 2000 this share had risen to around 17 per cent. The USA is a major player in cross-border acquisitions in the food sector (and manufacturing and services more generally) accounting for, by value for the 1987-2000 period, 15 per cent of total manufacturing sector acquisitions abroad although, taking the USA as a target country, the food sector accounted for a lower 8 per cent of total US manufacturing targets. Food sector acquisition activity involving EU countries accounted for 15 per cent of acquisitions across the EU manufacturing sector and 11 per cent of targets over the same period. The UK, the Netherlands, France and Germany are major active EU countries in the market for corporate control in the food sector. Moreover, in any particular year, cross-border acquisitions involving firms in the food sector often top the league table of deal values in general. For example, in 2000 Unilever PLC (a UK/Dutch firm) acquired the US firm BestFoods for US $\$ 25$ billion, the second most expensive acquisition of a US company that year while in 1999 the most significant cross-border deal by any US company was WalMart's acquisition of Asda Group PLC for around US\$11 billion. To summarise, the food sector is one of the leading sectors for acquisition activity in both the US and the EU.

The aim of this paper is to explore the determinants of the distribution and growth of cross-border acquisitions in the food sector using a large panel data set comprising over 2,000 deals that involve 45 acquiring and 46 target countries over the period 1997-2004. This data is fairly comprehensive in terms of covering almost all cross-border acquisitions in the food sector over this period. We tie the determining variables to the recent literature on FDI. The data set we use here has several attractive features: first, unlike many studies in the general literature that focus on the US only, we have a large panel of the major countries involved in acquisition activity and this data allows us to explore the EU dimension; second, we can trace the 
growth and subsequent decline of international acquisitions across the 19972004 period which therefore captures the 'wave-like' features that have characterised FDI in the global economy in recent years; third, the data set also allows us to highlight differences along the supply chain. This separation is potentially important since the motivation for acquisitions may differ between agricultural-based food production, manufacturing-based food processing and service-oriented wholesaling and retailing of food. Taken together, given the role of cross-border acquisitions as the means of accessing markets, the analysis here will provide useful insights into an aspect of the food sector which has received comparatively little attention as well as being more comprehensive in coverage.

The paper is organised as follows. In Section 2, we outline in more detail the characteristics of cross-border acquisitions in the food sector worldwide. In Section 3, we provide a selective review of the literature that forms the basis for the econometric model to explore the determinants of cross-border acquisition activity over the 1997-2004 period. This is discussed in Section 4 while, in Section 5, we provide coverage of the results. In Section 6, we discuss some issues that relate to the robustness of our results and, in Section 7, we summarise and conclude.

\section{Characteristics of cross-border acquisitions in the food sector}

Data on cross-border acquisitions in the food sector are sourced from SDC Platinum database of Thomson Financial that claims to record virtually any deal involving a change in ownership of at least 5 per cent since the beginning of the 1990s. The analysis in this paper covers the period 1997-2004 where we identify a cross-border acquisition when an acquisition results in a parent firm holding a stake of at least 50 per cent of ownership in a target firm located abroad. ${ }^{2,3}$ In terms of covering the food and agricultural sector as a whole, we identify cross-border deals in SIC codes that relate to different aspects of the agricultural-food chain encompassing production, processing, wholesaling, and retailing. ${ }^{4,5}$ In identifying acquiring countries, we set the data to cover source countries that record any deals in these sectors. The common data set then provides us with 45 source countries making cross-

2 See footnote 1.

3 If the acquiring firm already had a stake in the target prior to acquiring in excess of 50 per cent of the shares, then this will be counted as a cross-border acquisition in our data. We also attempt to control for this in the econometric model.

4 Specifically, we search for international acquisitions in food production (SIC codes 01, 02 and 07), food processing (SIC 20), food wholesaling (SIC codes 5141-5154) and food retailing (SIC 54). In this context, we enlarge upon the definition of the food sector referred to in the UNCTAD data discussed above.

5 There may be other aspects of FDI that are missed including the role of private equity. This is to some extent unavoidable but it is worthy of note that most acquisition activity appears to be horizontal in nature (see below). We attempted to control for additional factors that may be related to private equity but these proved to be insignificant. 
Table 1. Cross-border acquisitions in the food sector, 1997-2004 by value (Million. US\$)

\begin{tabular}{lccccc}
\hline Year & Full sample & Production & Processing & Wholesale & Retailing \\
\hline 1997 & 15,392 & 118 & 9,816 & 875 & 1,003 \\
1998 & 13,762 & 129 & 8,758 & 521 & 3,842 \\
1999 & 19,859 & 135 & 12,170 & 0 & 4,860 \\
2000 & 51,636 & 259 & 44,391 & 20 & 2,111 \\
2001 & 26,860 & 49 & 21,441 & 25 & 876 \\
2002 & 21,436 & 53 & 19,571 & 66 & 1,342 \\
2003 & 6,012 & 19 & 4,847 & 0 & 882 \\
2004 & 9,908 & 22 & 7,894 & 35 & 1,444 \\
Total & 164,865 & 784 & 128,888 & 1,542 & 16,354 \\
\hline
\end{tabular}

Source: Compiled from Thomson Financial.

border acquisitions in the food sector across 46 target countries, the list of which being reported in Appendix 1.

The total recorded values of cross-border acquisitions around the world over the 1997-2004 period are reported in Table 1. There are two notable features from this table: first, the value of cross-border acquisitions in the food sector increased markedly from 1997 to 2000, reaching a peak of US $\$ 51,636$ million and subsequently declined following 2000 . This reflects the 'wave-like' feature of world FDI that has been common across all sectors. ${ }^{6}$ Second, in terms of the distribution of cross-border acquisitions in the food sector, food processing dominates accounting for 78 per cent of the value of international acquisitions followed by food retailing with 10 per cent and wholesaling and agricultural production being only minor activities. ${ }^{7}$

International acquisition activity is concentrated among a relatively small number of countries. In particular, as summarised in Table 2, the US, the Netherlands, France and the UK account for more than 63 per cent of international acquisitions within the current sample with these leading countries following the pattern of the total sample insofar as experiencing a rise and fall in the total value of deals over the 1997-2004 period as well as food processing dominating overall acquisition activities.

To complete the overview of the data, Table 3 reports the number of crossborder acquisitions in the food sector over the sample period ranked in order of importance. The count data contain over 2,000 completed acquisitions worldwide with the US being the lead acquiring country recording 336 crossborder acquisitions, followed by the Netherlands, France and the UK. Together these four countries financed around 45 per cent of all cross-border deals in the food sector. Again, food processing dominates cross-border

6 See also Brakeman et al. (2006) for a discussion of the wave-like behaviour of cross-border acquisitions.

7 When looking at the distribution and growth in terms of CBA counts instead of values, the surge of international merger activity around the year 2000 emerges with food processing adopting a similarly dominant position. 
Table 2. Cross-border acquisitions in the food sector by leading acquiring countries (US, Netherlands, France and the UK), 1997-2004 by value (Million. US\$)

\begin{tabular}{lccccc}
\hline Year & Full sample & Production & Processing & Wholesale & Retailing \\
\hline 1997 & 6,389 & 21 & 4,334 & 831 & 1,003 \\
1998 & 7,513 & 129 & 3,073 & 206 & 3,842 \\
1999 & 13,840 & 0 & 6,738 & 0 & 4,554 \\
2000 & 42,956 & 2 & 37,031 & 20 & 1,533 \\
2001 & 9,865 & 0 & 4,787 & 25 & 753 \\
2002 & 10,514 & 5 & 9,367 & 20 & 1,013 \\
2003 & 4,687 & 13 & 4,411 & 0 & 0 \\
2004 & 8,160 & 14 & 6,470 & 0 & 1,336 \\
Total & 103,924 & 184 & 76,211 & 1,102 & 14,034 \\
\hline
\end{tabular}

Source: Compiled from Thomson Financial.

acquisitions accounting for 71 per cent of all deals. Conversely, the proportion of food retailing was just over 6 per cent with wholesaling and the agricultural production of food accounting for less than 3 per cent of deals over the sample period. ${ }^{8}$ Though only a minor share of deals occurred in food wholesaling and production, their relative importance was somewhat greater in countries such as Hungary, Argentina, Australia and nations with major seaports such as Singapore and the Netherlands, respectively. Finally, the last column of Table 3 reports international acquisitions across all sectors. With a total number of deals of almost 50,000, the food sector held about a 4 per cent share in the worldwide market for corporate control. ${ }^{9}$

\section{Recent research on FDI}

FDI has long attracted interest from trade economists with research on this topic pursuing disparate themes, although in recent years there has been renewed interest focusing on the motivation for different forms of FDI, the alternative ways in which FDI may occur as well as focusing on the crosscountry and time series characteristics of FDI, reflecting the wave-like behaviour noted above. Barba-Navaretti and Venables (2004) provide a recent overview of some of these issues. Reflecting recent empirical research, these themes form the basis for the empirical section of this paper.

One important theme in the recent literature has been incorporation of horizontal (market-driven) and vertical (endowment-based) motives for FDI into a unified framework associated most notably with the work of Markusen (2002) and Markusen and Venables (1998) labelled the 'knowledge-capital' model of FDI. More recent research goes beyond this by accounting for complex strategies where the acquisition of foreign affiliates may establish export platforms

8 Given the possibility to invest across the stages of the agricultural-food supply chain, e.g. from food processing into food retailing, these figures do not add up to 100 per cent.

9 Note, this figure is lower than those reported above as this figure relates to corporate acquisitions in manufacturing and services. 
Table 3. Cross-border acquisitions in the global food sector, 1997-2004

\begin{tabular}{|c|c|c|c|c|c|c|c|}
\hline \multicolumn{2}{|c|}{ Source Country } & \multicolumn{5}{|c|}{$\begin{array}{l}\text { Cross-border acquisitions (CBAs) in the Food } \\
\text { Industry (Count) }\end{array}$} & \multirow[t]{2}{*}{ All CBAs } \\
\hline Rank & Name & Production & Processing & Wholesale & Retail & All & \\
\hline 1 & United States & 16 & 240 & 10 & 4 & 336 & 12,949 \\
\hline 2 & Netherlands & 4 & 125 & 6 & 42 & 203 & 2,289 \\
\hline 3 & France & 5 & 126 & 2 & 15 & 188 & 2,834 \\
\hline 4 & United Kingdom & 4 & 123 & 5 & 13 & 173 & 6,183 \\
\hline 5 & Germany & 3 & 69 & 3 & 5 & 102 & 3,566 \\
\hline 6 & Ireland & 0 & 69 & 5 & 3 & 92 & 688 \\
\hline 7 & Canada & 1 & 58 & 2 & 5 & 90 & 4,037 \\
\hline 8 & Denmark & 4 & 69 & 2 & 2 & 86 & 910 \\
\hline 9 & Switzerland & 1 & 65 & 0 & 0 & 81 & 1,378 \\
\hline 10 & Belgium & 1 & 64 & 4 & 1 & 78 & 1,060 \\
\hline 11 & Australia & 5 & 36 & 2 & 2 & 52 & 1,222 \\
\hline 12 & Italy & 2 & 40 & 1 & 0 & 52 & 989 \\
\hline 13 & Sweden & 0 & 40 & 1 & 6 & 52 & 1,739 \\
\hline 14 & Spain & 0 & 33 & 1 & 1 & 42 & 934 \\
\hline 15 & Finland & 0 & 28 & 1 & 2 & 38 & 931 \\
\hline 16 & Norway & 0 & 29 & 0 & 2 & 36 & 699 \\
\hline 17 & Singapore & 1 & 24 & 4 & 1 & 33 & 1,157 \\
\hline 18 & Japan & 1 & 14 & 0 & 2 & 25 & 1,089 \\
\hline 19 & Austria & 2 & 17 & 1 & 3 & 24 & 730 \\
\hline 20 & South Africa & 1 & 13 & 2 & 4 & 22 & 434 \\
\hline 21 & New Zealand & 0 & 15 & 0 & 0 & 21 & 246 \\
\hline 22 & Argentina & 4 & 11 & 0 & 3 & 20 & 111 \\
\hline 23 & Greece & 1 & 15 & 0 & 1 & 20 & 248 \\
\hline 24 & Mexico & 0 & 17 & 1 & 0 & 20 & 167 \\
\hline 25 & Malaysia & 1 & 12 & 0 & 0 & 19 & 578 \\
\hline 26 & Israel & 0 & 12 & 0 & 0 & 14 & 302 \\
\hline 27 & Brazil & 0 & 9 & 1 & 0 & 12 & 111 \\
\hline 28 & Estonia & 0 & 7 & 0 & 2 & 9 & 54 \\
\hline 29 & Korea & 0 & 7 & 0 & 0 & 8 & 218 \\
\hline 30 & Chile & 0 & 5 & 0 & 0 & 7 & 82 \\
\hline 31 & Hungary & 2 & 1 & 0 & 1 & 7 & 91 \\
\hline 32 & Philippines & 0 & 5 & 0 & 0 & 7 & 56 \\
\hline 33 & China & 1 & 3 & 1 & 0 & 6 & 358 \\
\hline 34 & Colombia & 0 & 6 & 0 & 0 & 6 & 37 \\
\hline 35 & India & 0 & 5 & 0 & 0 & 6 & 331 \\
\hline 36 & Portugal & 0 & 5 & 0 & 1 & 6 & 189 \\
\hline 37 & Czech Rep. & 0 & 3 & 0 & 0 & 4 & 66 \\
\hline 38 & Lithuania & 0 & 3 & 0 & 0 & 4 & 29 \\
\hline 39 & Peru & 0 & 2 & 0 & 0 & 3 & 12 \\
\hline 40 & Poland & 0 & 3 & 0 & 0 & 3 & 63 \\
\hline 41 & Turkey & 0 & 2 & 0 & 0 & 3 & 61 \\
\hline
\end{tabular}


Table 3. (continued)

\begin{tabular}{|c|c|c|c|c|c|c|c|}
\hline \multicolumn{2}{|c|}{ Source Country } & \multicolumn{5}{|c|}{$\begin{array}{l}\text { Cross-border acquisitions (CBAs) in the Food } \\
\text { Industry (Count) }\end{array}$} & \multirow[t]{2}{*}{ All CBAs } \\
\hline Rank & Name & Production & Processing & Wholesale & Retail & All & \\
\hline 42 & Bulgaria & 0 & 1 & 0 & 0 & 1 & 8 \\
\hline 43 & Cyprus & 0 & 0 & 0 & 1 & 1 & 81 \\
\hline 44 & Indonesia & 0 & 1 & 0 & 0 & 1 & 59 \\
\hline \multirow[t]{2}{*}{45} & Latvia & 0 & 1 & 0 & 0 & 1 & 29 \\
\hline & Total & 60 & 1,433 & 55 & 122 & 2,014 & 49,405 \\
\hline
\end{tabular}

Source: Compiled from Thomson Financial.

to supply outlets located in other countries where market access constitutes the main driving force (Yeaple, 2003). ${ }^{10}$ Against this background, the main aim of the recent empirical literature has been to explore whether or not alternative motives for FDI are evident in the data with Carr et al. (2001) constituting a widely cited example, the focus being to interpret the significance of the appropriate variables (market size, endowment differences) relating to the horizontal and vertical motivations for FDI. These variables form the basis of gravity-based models of FDI and (as we note below) have been used to address the distribution and growth of cross-border acquisitions.

Another main theme in the FDI literature pertinent to our empirical strategy is to account for its time series features that characterise the recent pattern of cross-border acquisitions in the world economy. As noted above, FDI in the world economy exhibits a 'wave-like' behaviour. Such significant movements in FDI do not sit well with standard general equilibrium trade/FDI models that focus on market size and relative endowments to account for the distribution of FDI. To explain these phenomena, research has highlighted the role of exchange rates and stock market activity with these factors determining the relative wealth of firms acquiring overseas targets. Froot and Stein (1991) and Klein and Rosenberg (1994) are examples of this line of research while Blonigen (1997) explores the role of exchange rates in determining the returns for acquiring firms. The central rationale here relates to relative wealth effects. In the context of imperfect capital markets, changes in relative wealth (captured by the real exchange rates or the change in stock market values in the acquiring country) may allow an acquirer to bid successfully for a target when the change in the exchange rate reduces the budget constraint on the foreign buyer.

The final theme (and most relevant one given the data used in this paper) relates to the form that the foreign investment takes. Despite the dominance

10 The issue of export platform FDI, while likely to be important, has received only limited attention in the empirical literature to date. An interesting contribution can be found in Blonigen et al. (2007) who employ a spatial econometric approach to gauge the relevance of third countries as a determinant of FDI flows. 
of cross-border acquisitions as the main vehicle for FDI, few studies have focused on this issue. Evenett (2003) highlights the importance of international acquisitions in the world economy. Recent theoretical work on FDI has focused on the mode of market entry including Nocke and Yeaple (2007) and Neary (2007). Meanwhile, the cross-country determinants of international merger deals received attention from Rossi and Volpin (2004) though the focus of this paper is on the interaction between finance and the rule of law as opposed to market size and relative endowments that have been the feature of the trade literature. Perhaps closest to the approach adopted below is the paper by Di Giovanni (2005) who employed a gravity model to explain the distribution and growth of cross-border acquisitions around the world. In the empirical section below, we draw upon these recent developments to inform the likely determinants of cross-border acquisitions in the food sector. ${ }^{11}$

Studies on FDI in the food sector are relatively sparse with most research being confined to the US. Connor (1983) is an early example of an empirical study of the determinants of FDI with more recent studies varying in their coverage and focus. ${ }^{12}$ As far as we are aware, the work by McCorriston and Sheldon (1998) is the only study on cross-border acquisitions in the food sector, though again their data is limited to the US. Moreover, they find that the determinants of the acquisitions in the US food sector differed from other sectors comprising US manufacturing insofar as the determinants of cross-border acquisitions across sub-sectors of US manufacturing did not appear to apply to the US food sector. However, their sample was small and this perhaps causes the evidence on the determinants of US acquisition activity in the food sector to be weak. Given the importance of cross-border acquisitions in the food sector worldwide, further attention is warranted.

Although these studies have not been necessarily motivated by the specific idea that the determinants of FDI will vary across sectors, there is nevertheless some reason to believe this will be the case. Specifically, recent work on trade has identified that the number of firms from each sector that participate in trade and foreign investment is very small relative to the universe of active firms. Bernard et al. (2007) provide recent coverage of this issue. This so-called heterogeneity highlights differences across sectors as determining the participation of firms in international markets. In this spirit, we also apply the econometric model to various cuts in the data on the premise that with underlying heterogeneity within the food sector (specifically across stages), we may therefore also expect the determining factors to vary. For example, market size, stock market valuations or property rights may be an important determinant of all cross-border acquisitions, but may matter to different degrees for specific industries. ${ }^{13}$

11 Complementing the empirical approaches to the form of FDI noted above, most cross-border acquisitions (at the 2 digit SIC) are horizontal in nature. See also Brakeman et al. (2006).

12 Other studies of FDI in the food sector (including those using non-US data) include: Ning and Reed (1995), Anastassopolulos and Traill (1998), Gopinath et al. (1999), Benito (2000), Barkley (2005), Guiletti et al. (2004) and Tozanli (2005).

13 See reference to McCorriston and Sheldon (1998) above and Cho et al. (2002). 


\section{Determinants of cross-border acquisitions}

\subsection{General considerations}

Empirical analysis of FDI has typically been hindered by access to comprehensive and detailed data with many studies relying on stock or flow data with country and sector coverage often being limited or the data unreliable. However, given the observation that most FDI takes the form of cross-border acquisitions, in recent years there has been increased use of financial data sets that directly record this activity. These sources record two related aspects of cross-border acquisitions; the number of acquisitions made and also the value of these acquisitions. Each relates to different stages in the decision tree in terms of acquisition activity, but there are also practical advantages focusing on the number of acquisitions made. First, despite the claim of comprehensive coverage, in many cases merging companies do not disclose the deal value, and the SDC Platinum database merely records that a deal has been made. ${ }^{14}$ As such, counting the number of deals gives a fuller picture of global cross-border activity. Second, in recent years, the noted overvaluation in stock markets has also influenced the total value of acquisitions and has also involved a number of so-called 'mega' deals; as such, relying on value data may also distort the overall significance of the factors driving the locational choice of acquiring firms.

Aside from these practical issues, the count and value dimension are related but distinct stages in the decision-tree for multinational firms. As Devereux and Griffith (1998) and Devereux (2006) note, the choice of one location over another is essentially a discrete variable. Having made the decision to locate in a given country, the acquiring firm subsequently decides how much to invest in the target country and this is a continuous variable. ${ }^{15}$ To this end, and also given the practical issues about greater data availability on the number of recorded deals, we primarily use a panel count data model to address the distribution and growth of cross-border acquisitions over the sample period and this directly concurs with the location choice in the decision tree. However, values are a related but distinct aspect of the story and we also consider whether the factors driving the total level of acquisition activity in terms of the number of firms also influences total values. Of course, the coefficients relate to different aspects of the decision process but a priori we may expect the driving factors to be the same. For example, we may expect more firms to choose to target firms where market size is larger; by extension, the total value of deals may be expected to be greater in larger markets. Reflecting these issues, our methodology fits with recent practice in addressing FDI activity

14 In terms of covering global acquisitions, this truncation of the value data is substantial with more than 50 per cent of the recorded deals not reporting a corresponding value.

15 As with most models of FDI, the underlying framework here is one of firm entry. Nevertheless, divestiture is another important aspect of firm behaviour. This should only affect the sample here to the extent that the divestiture involves the sale to another foreign acquiring firm which is unlikely to be a significant feature of the data. 
in the world economy with a number of recent papers focusing on count econometric models to address the distribution and growth of cross-border acquisitions including Bertrand et al. (2004), Hijzen et al. (2008), Huizinga and Voget (2006) and Kessing et al. (2007).

As with recent empirical work, we employ a gravity specification to explain the distribution and growth of cross-border acquisitions around the world. ${ }^{16}$ We draw upon the literature on the theory of FDI in selecting the independent variables. In broad terms, as outlined above, this research highlights the role of market size and relative wage costs reflecting alternative motivations (horizontal and vertical) as summarised in Markusen (2002) and Carr et al. (2001). Moreover, financial factors such as exchange rates and stock market growth feature in Froot and Stein (1991), Blonigen (1997) and Klein and Rosenberg (1994) and have been explored by Di Giovanni (2005) to explain subsequent booms and troughs in the growth of FDI. We also control for investment costs which increase, for example, in environments with poor institutional quality as highlighted by Rossi and Volpin (2004) but are also affected by the tax burden levied upon foreign investments into local affiliates (see, for example, Devereux and Griffith, 1998). In terms of additional controls, we also account for trade costs and preferential trading arrangements that may determine the costs and benefits of acquiring a firm abroad and the preference for one location as opposed to another.

As noted above, we focus primarily on the number rather than the value of acquisitions as this mitigates against sample selectivity; results on the total value of acquisitions are also reported below. In terms of the count dimension, estimation conditions the expected number, $\lambda_{i j, t}$, of cross-border acquisitions $\left(C B A_{i j, t}\right)$ between acquiring country $i$ and target country $j$ in time $t$ through the exponential mean function:

$$
\begin{aligned}
\lambda_{i j, t}= & E\left[C B A_{i j, t} \mid X_{i j, t}\right] \\
= & \exp \left(\text { marketsize }_{i j, t}, \text { relativecost }_{i j, t}, \text { trade } \cos t_{i j, t},\right. \\
& \text { financialfactors }_{i j, t},{\text { inv } \left.\cos t_{j, t}\right)}
\end{aligned}
$$

on control variables marketsize $i_{i j, t}$, relativecost $t_{i j, t}$, tradecost $_{i j, t}$, financialfactors $_{i j, t}$ and invcost $t_{j, t}$ which have been discussed above. The exponential transformation is warranted to account for the non-negative nature of acquisition count data.

Although the conditional mean specification (1) relates cross-border acquisitions systematically to explanatory variables, $X$, it does not fully describe the count distribution allowing for maximum likelihood estimation. Thereto, the probability mass function, $\operatorname{Prob}\left[C B A_{i j, t}=C B A \mid X_{i j, t}\right]$, of $C B A$ s conditional on $X$ needs specifying. Unlike the Poisson count model where the conditional 
mean equals the conditional variance, that is $E\left[C B A_{i j, t} \mid X_{i j, t}\right]=\operatorname{Var}\left[C B A_{i j, t}\right.$ $\left.\mid \mathrm{X}_{i j, t}\right]=\lambda_{i j, t}$, to allow for the possibility of over-dispersion, a negative binominal distribution is adopted. Then, the conditional variance may exceed the mean at a rate $\operatorname{Var}\left[C B A_{i j}, t \mid X_{i j, t}\right]=\lambda_{i j, t}+\alpha \lambda_{i j, t}^{2}$ with $\alpha$ designating an overdispersion parameter. ${ }^{17}$ Given the longitudinal nature of our data, where international merger activity is observed over eight consecutive years for the same acquiring and target nations, the additional randomness is likely to arise from country-pair specific, but unobserved, heterogeneity. ${ }^{18}$

\subsection{Data issues}

The dependent variable is the number of acquisitions between country $i$ and country $j$ in time $t$ sourced from Thomson Financial. We consider several variants of this variable. For the sake of comparison, the total number of acquisitions across all sectors has been counted before isolating deals within the food sector, which cover more than 2,000 acquisitions over the 1997-2004 period. This would allow us to identify (in an aggregate manner) whether crossborder acquisitions in the global food sector differ from acquisitions in other sectors. In addition, noting the discussion above where we can separate acquisitions along the agricultural-food supply chain, we also run the model on acquisitions in sub-sectors. This allows us to explore the possibility that the factors determining acquisitions in, for example, food processing or retailing may differ from those in the food sector more generally. Finally, given that factors determining FDI across regions may differ (for example, institutional quality may be lower in developing countries but high in developed countries), we also cut the data by region. In particular, sub-samples separate acquisitions towards developed countries with, according to the World Bank classification, high and upper-middle incomes and developing countries with low and lowermiddle incomes. ${ }^{19}$ Furthermore, cross-border merger activity within the EU and the Euro-zone is also addressed given the expectation that adoption of the Euro may have influenced cross-border acquisition activity.

As discussed above, we draw on the recent theoretical and empirical literature in our selection of the determining variables. Market size relates to the product of GDP between country $i$ and country $j$ in time $t$ (Carr et al., 2001). The expected sign on this variable is positive suggesting that larger markets attract more FDI. This variable refers to market access considerations for

17 This version of the negative binominal models (NEGBIN) is commonly labelled as NEGBIN II. In case of the NEGBIN I specification, the variance increases linearly instead of quadratically in the conditional mean. By and large, our conclusions remain unaffected by the choice of the exact negative binominal model.

18 Count models that explicitly account for issues arising with longitudinal data have been developed (see Cameron and Trivedi, 1998, ch. 9). Owing to its predominant usage in applied work, we employ the standard NEGBIN and deal with alternative count regression techniques as a robustness issue in Section 6.

19 With only 50 out of more than 2,000 deals within the food industry, during the period under consideration, the market for corporate control of developing countries was of negligible size. Thereby, a mere 18 deals involved developing countries as acquiring and target nation. 
FDI. Meanwhile, the vertical motivation for FDI is captured by the variable relating to relativecosts $s_{i j, t}$ between the source and host countries. Obtaining appropriate measures for this variable proved difficult for a large cross section of countries. In this paper, we follow Braconier et al. (2005) and use data on prices and earnings published by UBS that offer a wage index based on the hourly income of comparable professions across the countries in our sample. ${ }^{20}$ In their study, Braconier et al. ascertain the existence of vertical FDI if this variable appears as a significant determinant of FDI. However, since relative rather than absolute endowments drive vertical FDI, we construct a relative cost variable in terms of international differences in wages $\left(\Delta w_{a g} e_{i j, t}\right)$. The expectation is that this variable should be positive as the desire to outsource stages in the chain of food production, processing and distribution increases the more wage costs in source country $i$ differ from the host country $j$.

To measure trade costs, we consider three variables. ${ }^{21}$ Common to most gravity models' we use distance ${ }_{i j}$ between countries $i$ and $j$ and a variable for language $_{i j}$, the latter being a binary variable reflecting the existence of a common language between countries $i$ and $j$. While the existence of a common language will be expected to be positive, distance will be expected to have a negative influence. In the finance literature, the role of distance in affecting financial flows is a proxy for asymmetric information and the difficulty in monitoring the investments made. ${ }^{22}$ See, for example, Portes and Rey (2005). Finally, customs unions designing shared policies as in the EU may dismantle non-tariff barriers to cross-border trade thereby inducing further investment across a common market, an important consideration given the large number of acquisitions involving European countries.

Corporate taxes have received considerable attention in the public finance literature and are reviewed by De Mooij and Ederveen (2003). To measure this impact, top marginal tax rates levied on corporations are employed with the variable being constructed as a tax differential variable to capture the relative after-tax profits associated with the decision to stay domestic or acquire abroad. However, aside from taxes, institutional quality as reflected in the protection of property rights and the regulatory cost of doing business further affect investment across host countries. Trivially, poor protection of property rights (measured by a perception-based index) and high costs of regulation (related to the number and duration of procedures to setting up a firm) would be expected to deter investors. ${ }^{23}$

20 Alternative measures are used in the literature though in many cases this has often reflected difficulty in accessing appropriate data. For example, Di Giovanni (2005) employed GDP per capita to proxy for wage differentials. The paper by Braconier et al. (2005) suggests the use of more direct data on relative wages which is the data source that is utilised in this paper.

21 The issue of explicit trade barriers is addressed in Section 6 below but due to the extensive nature of the data set and the breakdown across sectors, it is difficult to include tariffs in the baseline estimation.

22 This is in contrast say to the use of trade flows where distance may serve to proxy for transportation costs.

23 See Djankov et al. (2002) for a discussion of issues relating to the costs of regulation across a large sample of countries. 
Exchange rates between countries $i$ and $j$ and stock market capitalisation in the source country $i$ account for the financial determinants of cross-border acquisitions. Following Froot and Stein (1991) and Blonigen (1997), the role of the exchange rates $\left(\right.$ exrate $\left._{i j, t}\right)$ is expected to be negative suggesting that an appreciation of the exchange rate will lead to lower cross-border acquisitions from the source country. Higher stock market capitalisation in the source country will improve the relative wealth of the acquiring firms and should have a positive influence on acquisitions. These factors will likely be the key determinants of the 'wave-like' behaviour that is evident in the time series behaviour of the FDI/cross-border acquisition data. In addition, to capture the possibility of acquisitions involving increasing share ownership of firms already based in the host country, we also included the stock market index of the target country in the econometric model.

In sum, the model we estimate is given by:

$$
\begin{aligned}
E\left[C B A_{i j, t} \mid X_{i j, t}\right]= & \exp \left(\beta_{0}+\beta_{1} \text { gdp }_{i, t} \cdot \text { gdp }_{j, t}+\beta_{2} \Delta \text { wage }_{i j, t}+\beta_{3} \text { distance }_{i j}\right. \\
& +\beta_{4} \text { LANGUAGE }_{i j}+\beta_{5} \text { CU }_{i j, t}+\beta_{6} \text { taxdiff }_{j i, t} \\
& +\beta_{7} \text { entrycost }_{j, t}+\beta_{8} \text { proprights }_{j, t} \\
& \left.+\beta_{9} \text { stock }_{i, t}+\beta_{10} \text { stock }_{j, t}+\beta_{11} \text { exrate }_{i j, t}\right)
\end{aligned}
$$

Appendix 2 reports details on the construction and sources of the data set. All independent variables except for the indicators for language and customs unions have been transformed into logarithms, which mitigates against heteroscedasticity. When employing count regressions, the coefficient of logarithmic variables represent estimates of (constant) elasticities which, insofar as measuring the conditional impact of a percentage change upon the percentage change in merger counts, facilitates the interpretation of the magnitude of coefficients. The results of estimating equation (2) are reported in the next section.

\section{Results}

Table 4 reports the results relating to the determinants of global acquisitions in the food sector. The first column covers all stages in the food chain while columns 2 and 3 report separately the results for acquisitions in food processing and retailing, respectively. All of the determining variables have signs consistent with economic priors and most are statistically significant at the 1 per cent level with the exception of the effect of preferential trading arrangements, the protection of property rights and the role of exchange rates, all of which fail to produce a significant impact within the global food sample (column 1).

Relating the results to recent developments in the theory of FDI confirms the importance of market size and relative costs in determining food sector acquisitions across countries. The role of market size is not surprising given that a large part of FDI in the food sector occurs between developed countries 
Table 4. Determinants of cross-border acquisitions in the food sector

\begin{tabular}{|c|c|c|c|c|}
\hline $\begin{array}{l}\text { Supply-chain stage: Dependent } \\
\text { variable }\end{array}$ & $\begin{array}{l}\text { All stages number } \\
\text { (1) }\end{array}$ & $\begin{array}{l}\text { Processing number } \\
\text { (2) }\end{array}$ & $\begin{array}{l}\text { Retailing number } \\
\text { (3) }\end{array}$ & $\begin{array}{l}\text { All stages value } \\
\text { (4) }\end{array}$ \\
\hline$g d p_{i, t}{ }^{*} g d p_{j, t}$ & $0.477 * * *(0.025)$ & $0.490 * * *(0.029)$ & $0.235 * *(0.112)$ & $363.1 * * *(32.41)$ \\
\hline$\Delta$ wage $_{i j, t}$ & $0.564 * * *(0.070)$ & $0.561 * * *(0.078)$ & $0.532(0.342)$ & $432.2 * * *(82.08)$ \\
\hline distance $_{i j}$ & $-0.857 * * *(0.045)$ & $-0.858 * * *(0.052)$ & $-0.614 * * *(0.222)$ & $-601.8 * * *(60.68)$ \\
\hline$L A N G U A G E_{i j}$ & $1.150 * * *(0.108)$ & $1.142 * * *(0.120)$ & $1.244 * *(0.495)$ & $952.5 * * *(134.5)$ \\
\hline$C U_{i i, t}$ & $-0.015(0.110)$ & $-0.005(0.128)$ & $0.626(0.500)$ & $-214.2(153.6)$ \\
\hline $\operatorname{taxdiff}_{j i, t}$ & $-0.370 * * *(0.094)$ & $-0.372 * * *(0.105)$ & $-1.141 * *(0.536)$ & $-177.1(129.1)$ \\
\hline entrycost $_{j, t}$ & $-0.261 * * *(0.038)$ & $-0.254 * * *(0.043)$ & $-0.092(0.178)$ & $-264.3 * * *(47.54)$ \\
\hline propright $_{j, t}$ & $-0.112(0.213)$ & $-0.127(0.240)$ & $0.072(1.012)$ & $-272.9(276.4)$ \\
\hline stock $_{i, t}$ & $0.275^{* * *}(0.042)$ & $0.228 * * *(0.047)$ & $0.631 * * *(0.203)$ & $302.8 * * *(60.38)$ \\
\hline stock $_{j, t}$ & $-0.008(0.032)$ & $-0.017(0.039)$ & $0.360 * *(0.159)$ & $76.79(49.25)$ \\
\hline exrate $_{i j, t}$ & $-0.071(0.075)$ & $-0.094(0.083)$ & $-0.154(0.282)$ & $-3.723(79.52)$ \\
\hline Intercept & $4.670 * * *(0.433)$ & $4.403 * * *(0.513)$ & $-1.136(2.015)$ & $2,565 * * *(541.0)$ \\
\hline$\alpha$ & $1.855^{* * *}(0.149)$ & $1.745 * * *(0.192)$ & $15.88 * * *(4.752)$ & \\
\hline$\sigma$ & & & & $1,824 * * *(68.83)$ \\
\hline$N$ & 9,482 & 9,482 & 9,482 & 7,851 \\
\hline Log likelihood & $-2,756$ & $-2,177$ & -395.9 & $-4,234$ \\
\hline
\end{tabular}

Note: Columns 1-4 have been estimated by Count regressions, which rest on a negative binominal distribution and a log-linear mean specification (Negbin II Model) with $\alpha$ designating the estimated over-dispersion parameter. Columns 5 and 6 have been estimated by Tobit regressions with $\sigma$ designating the extent of censoring (at a value of zero from the left). Standard errors are in parentheses. Coefficients significant at the $10 \%$ level are labelled with a $*$, at the $5 \%$ level with $* *$ and at the $1 \%$ level with $* * *$. Variables in small letters have been transformed into logarithms, e.g. $x=\ln (X)$, meanwhile CAPITAL letters designate nominal (dummy) variables. Columns 4 and 6 relate to all CBAs, columns 1 and 5 to all CBAs in the food sector, from 46 source countries to 51 host countries for each year between 1997 and 2004. Columns 3 and 4 isolate CBAs conducted at the stage of food processing and food retailing, respectively. 
though the statistical significance of the relative cost variable also suggests that vertical motivations play a role in explaining the distribution of acquisitions in the food sector worldwide. This is consistent with the approach of Braconier et al. (2005) who interpreted the vertical motivation for FDI relating to the significance of the (relative) wage variable. ${ }^{24}$ Frictional factors also appear important with distance reducing cross-border acquisitions while the existence of a common language between host and source countries has a positive influence. Finally, in terms of explaining the distribution of international acquisitions across countries, the cost of doing business in the host country impacts negatively upon acquisitions. Notably, the non-significant role for property rights may reflect the fact that most deals in the food sector occur between developed countries where institutional quality would be expected to be high or that intangible assets necessitating a strong protection from the threat of expropriation are not important when acquiring foreign food companies.

In terms of explaining the 'wave-like' pattern of acquisitions in the world economy in the food sector, it would appear that fluctuations in stock markets in the source country have been the driving force. Recall from the discussion above that this variable captures relative wealth effects in the market for corporate control. ${ }^{25}$ Notably, unlike previous studies (see, for example, Di Giovanni, 2005), the role of financial development in the host country does not appear to play a role (again perhaps reflecting the concentration of developed countries as the main sources and hosts of cross-border acquisitions in the food sector) nor does the exchange rate. Clearly, for the food sector, fluctuations in stock market valuation appear to be the major driver of the observed 'wave-like' behaviour of acquisitions over the sample period.

Columns 2 and 3 of Table 4 separate out the results for acquisitions in the food processing and retailing sectors. ${ }^{26}$ To recall, the motivation for exploring this is that the factors fostering cross-country acquisitions may vary along the stages of the agricultural-food supply chain. The results confirm this to be the case. While to some extent cross-border acquisitions are driven by common factors, most notably, market size and trade frictions such as distance and language, there are some key differences. For example, relative wages are statistically significant at the 1 per cent level for food processing but insignificant for retailing. This perhaps is not surprising given that acquiring a target in the retailing sector will be principally motivated by market size though it is also

24 Employing relative wages is not free of caveats. In particular, Blonigen et al. (2003) suggest to apply absolute values to mitigate against sign reversals arising with positive and negative wage differences, Here, relative wages have been transformed into logarithmic differences, i.e. $\Delta$ wage $_{i j}=\log \left(\right.$ wage $_{i} /$ wage $\left._{j}\right)$ implying a marginal impact in terms of a constant elasticity, thus being robust towards sign reversals.

25 On the suggestion of a referee, we also allowed for path dependence by including acquisitions in the previous year. This was significant but did not affect the direction of the impact or the significance of the other variables, nor could we find a rationalisation for it in the theoretical literature, so we excluded it from the presentation of the results here.

26 Recall from Table 3 that most international acquisitions arise in food processing and retailing. Since cross-border acquisitions in food production and wholesaling are very low, we do not report the results for these sub-samples here. 
notable that the estimated coefficient is higher for this variable in food processing than retailing. Other substantial differences across these two sub-samples include relative corporate taxes having a highly significant effect in food processing but less so on retailing, entry costs affecting processing but not retailing while the stock market effect has an estimated elasticity in driving acquisitions in retailing that is, compared with the corresponding coefficient for food processing, more than double in magnitude. ${ }^{27}$ The stock market variable for the host country is also significant for the retailing sector but not for processing. With values of 194 and 1,816 for food processing and retailing, respectively, likelihood ratio statistics reject the hypothesis of equal coefficients between stages of the value chain and the food sector as a whole at any conventional level. These results confirm, thus, that the drivers of the location choice involving the food processing and retailing differ from the results given for the food sector as a whole. ${ }^{28}$

Recent research also suggests that factors driving FDI and international acquisitions differ according to geography (see, for example, Di Giovanni, 2005). To this end, we cut the global food sector sample to focus on acquisitions between different groupings of countries. These results are reported in Table 5. The first two columns report cross-border acquisitions in the food sector towards higher income (developed) countries only (column 1) and those involving lower income (developing) countries as the target nations (column 2). All variables have the expected signs, with many of these variables having high levels of statistical significance at the 1 per cent level though there are some notable differences according to the sub-sample. Of particular note is the lower income case where relative wages are insignificant suggesting that the main driving force for acquisitions in this grouping is market potential rather than seeking lower costs. In addition, corporate taxes are not significant in the higher income case but are in the lower income case, with entry costs being a greater barrier to acquisitions in the lower income case compared with the higher income case. Finally, the other notable difference relates to the variables principally capturing the growth of cross-border acquisitions over time. In the case of the higher and lower income groups, only the growth in stock markets in the source country matters but the impact of this for the lower income country is almost twice that compared with the high income group. Taken together, the results separating out acquisitions between developed countries only and those involving developing countries show important differences.

As a final cut of the data, we explore the determinants of cross-border acquisitions involving EU countries. Apart from the European interest, it is notable

27 Although the sub-samples are small, we did nevertheless explore the determinants of crossborder acquisitions involving production and wholesaling. Broadly, the results are consistent with the results for retailing and processing reported in Table 4 though relative wage costs were not significant in the wholesaling sub-sample and the exchange rate variable was significant in the production sample.

28 Similar tests with respect to the global food sample and cross-border acquisitions for manufacturing as a whole also confirmed that the drivers for the food sector differed from manufacturing in general. 
Table 5. Cross-border acquisition activity in the food sector: geographical breakdown

\begin{tabular}{|c|c|c|c|c|}
\hline \multirow[t]{2}{*}{ Acquirer and target nations } & \multicolumn{2}{|l|}{ All } & \multirow{2}{*}{$\begin{array}{l}\text { Within EU } \\
\text { (3) }\end{array}$} & \multirow[t]{2}{*}{ Within $€$-Zone } \\
\hline & $\begin{array}{l}\text { Higher income } \\
\text { (1) }\end{array}$ & $\begin{array}{l}\text { Lower income } \\
\text { (2) }\end{array}$ & & \\
\hline$g d p_{i, t}{ }^{*} g d p_{j, t}$ & $0.479 * * *(0.026)$ & $0.367 * * *(0.099)$ & $0.496 * * *(0.060)$ & $0.590 * * *(0.077)$ \\
\hline$\Delta$ wage $_{i j, t}$ & $0.715^{* * *}(0.078)$ & $-0.065(0.248)$ & $1.376 * * *(0.301)$ & $1.601 * * *(0.403)$ \\
\hline distance $_{i j}$ & $-0.826 * * *(0.047)$ & $-1.007 * * *(0.246)$ & $-1.014 * * *(0.167)$ & $-1.282 * * *(0.253)$ \\
\hline$L A N G U A G E_{i j}$ & $1.335^{* * *}(0.115)$ & $0.519(0.413)$ & $1.340 * * *(0.241)$ & $0.354(0.422)$ \\
\hline$C U_{i j, t}$ & $0.019(0.115)$ & $2.000(1.402)$ & & \\
\hline taxdiff $_{j i, t}$ & $-0.120(0.116)$ & $-0.962 * * *(0.326)$ & $0.163(0.320)$ & $0.006(0.476)$ \\
\hline entrycost $_{j, t}$ & $-0.233 * * *(0.040)$ & $-0.606 * * *(0.161)$ & $-0.055(0.066)$ & $-0.034(0.112)$ \\
\hline propright $_{j, t}$ & $-0.483(0.327)$ & $1.011 *(0.601)$ & $-0.335(0.793)$ & $0.052(1.079)$ \\
\hline stock $_{i, t}$ & $0.277 * * *(0.047)$ & $0.436 * * *(0.147)$ & $0.340 * * *(0.090)$ & $0.468 * * *(0.116)$ \\
\hline stock $_{j, t}$ & $0.018(0.035)$ & $0.238(0.167)$ & $0.362 * * *(0.073)$ & $0.382 * * *(0.088)$ \\
\hline exrate $_{i j, t}$ & $-0.021(0.077)$ & $-0.800(0.510)$ & $0.103(0.120)$ & $0.037(0.159)$ \\
\hline Intercept & $5.118 * * *(0.610)$ & $4.469 * * *(1.338)$ & $4.933 *(1.234)$ & $5.622 * * *(1.698)$ \\
\hline$\alpha$ & $1.706 * * *(0.145)$ & $1.406 * * *(0.550)$ & $1.044 * * *(0.163)$ & $0.945 * * *(0.201)$ \\
\hline$N$ & 7,733 & 1,749 & 1,228 & 800 \\
\hline Log likelihood & $-2,334$ & -376.9 & -743.1 & -427.6 \\
\hline
\end{tabular}

Note: Across various geographic sub-samples, this table presents estimates of the determinants of CBA activity within the food sector from 46 source countries to 51 host countries for each year between 1997 and 2004. Count regressions rest on a negative binominal distribution and a log-linear mean specification (Negbin II Model) with $\alpha$ designating the estimated over-dispersion parameter. Standard errors are reported in parenthesis. Coefficients significant at the $10 \%$ level are labelled with a *, at the 5\% level with ** and at the $1 \%$ level with $* * *$. Variables in small letters have been transformed into logarithms, e.g. $x=\ln (X)$ meanwhile CAPITAL letters designate nominal (dummy) variables. Columns 1 and 2 cut the sample according to whether the target (host) country belongs to the high and upper middle income or low and lower middle income group. Columns 3 and 4 single out deals undertaken within the European Union and the Euro-zone, respectively. 
that food sector acquisitions in the EU are a significant proportion of the food sector sample, with 57 per cent of total food sector acquisitions being financed by member countries. Moreover, in recent years, there have been important developments in the EU that may affect acquisition activity including the introduction of the Euro (that would have the potential effect of reducing the relative wealth effect that arises from exchange rate fluctuations), policy harmonisation and enlargement of the EU that are covered by our sample period. To deal with this, we consider acquisitions both within the EU generally - including those that have recently acceded to the EU - and then cut this sample to focus on those EU countries that adopted the Euro. The results relating to cross-border acquisitions in the EU food sector are reported in columns 3 and 4 of Table 5. There are some interesting observations to make from these sub-samples. Unsurprisingly, between these two sub-samples that focus on acquisitions in the EU, the variables have the same signs and comparable levels of significance. The most notable difference comes via the fact that the values of the coefficients differ being generally higher for the Euro-zone countries than for the EU generally. For example, the effect of stock market fluctuations has a stronger impact in the Euro-zone countries as does the effect of market size. Indeed, the estimated impact of these variables is stronger for the Euro-zone countries compared with global acquisitions in the food sector generally as reported in Table 4 (column 1). ${ }^{29}$

Taken together, the gravity-based model (comparable to that of Di Giovanni, 2005) provides an acceptable explanation of cross-border acquisitions in the food sector with most 'key' variables being statistically significant and being consistent with a priori expectations. However, the factors driving acquisitions in retailing and food processing tend to differ, international acquisitions involving developing countries differ from those involving developed countries only and there are important differences within the EU between those countries that are members of the Euro-zone. In sum, factors driving cross-border acquisitions can differ by geography and policy environment and by stage in the food chain, at least in terms of the impact individual variables have on the international acquisitions in the food sector.

\section{Further issues}

There are some outstanding issues in terms of the robustness of the explanatory factors offered in the models presented above. One issue is the role of trade barriers and the other relates to the values of acquisitions. With respect to trade barriers first of all, it is well-documented in the FDI literature that tariffs and other barriers can be an important impediment to locate or acquire another firm abroad. However, given the recent tendency towards increased intra-firm trade, the effect of trade barriers may be ambiguous

29 Again, these geographic differences in coefficients are statistically significant with respect to the model encompassing all cross-border acquisitions in the food sector. For the sake of brevity, corresponding likelihood ratio statistics are not reported here. 
since certain types of FDI may substitute (horizontal FDI) or complement (vertical FDI) trade. Despite this ambiguity, incorporating trade barriers in the initial specification would create problems for two main reasons. First, given the country coverage (45 source countries to 46 target countries), the sector-specific data will unlikely be available on a comprehensive basis exacerbated by the fact that the full sample also includes services; second, since we want to highlight factors determining acquisitions for the food sector as a whole (which comprises distinct vertical stages) and also by processing and retailing stages separately, it is not clear what the appropriate measure of trade barriers for highly-processed commodities would be compared with unprocessed commodities.

Nevertheless, we considered some possibilities. First, in the food sector samples, we included detailed data on tariffs for the food and agricultural sectors matching tariff data by the appropriate SIC codes. In terms of the retailing stage, to account for market access issues, we explored the role of the existence of service agreements between any two countries in the sample. These variables were positive but statistically insignificant though importantly for the discussion here, did not change the sign or statistical significance of any of the results presented in Tables 4 and 5.

Second, we considered whether the conclusions from the results based on the panel count model carry over to the case where we use values of the crossborder acquisitions as the dependent variable. As discussed above, the count and value dimensions of cross-border acquisitions relate to different levels in the decision tree of acquiring firms. Nevertheless, given that values are a closely-related dimension of cross-border activity, we may expect that the factors driving the total number and value of acquisitions to be broadly similar. To explore this, we have re-estimated our baseline results by means of Tobit regressions, which account in particular for the clustering of countrypairs not reporting any merger activity. Resulting coefficients enter the econometric model akin to equation (2) with the same sign and are reported in the final column of Table 4 . The sole difference relates to the tax variable that had a significant negative effect in the count model but not when focusing on values. One should note that, since these models relate to different dependent variables, the direct interpretation of the coefficients will differ; nevertheless, it is evident that the factors explaining alternative dimensions of the distribution and growth of cross-border acquisitions in the food sector are common to both the number and values of acquisitions.

Finally, we explored the issue of fixed versus random effects in the context of a panel count model. The appropriate Hausman test could not reject the random effects NEGBIN model in favour of a comparable fixed effects specification. ${ }^{30}$ Given the only difference between the NEGBIN and Poisson count models relates to the treatment of over-dispersion, we also explored whether the Poisson random effects was superior to the fixed effects model, and again

30 Owing to the likelihood function being not well-behaved, the fixed effects count model could only be established with an underlying Poisson distribution. 
the Hausman test statistic did not suggest rejection at any of the conventional levels. However, the significance of the variables in the base model reported in Table 4 above did not change when adopting random effects, though the values of the estimated coefficients were generally lower. By way of contrast, the fixed effects specification produced only significant coefficients on the stock market variables, which is maybe not surprising given their previously noted importance in explaining the time-varying dimension of international merger activity. Finally, based on the value data, the random effects Tobit model was yet again not rejected for a fixed effects model. Since the overall conclusions did not change in terms of the high level of significance of the determining variables, we are confident that the implications drawn out above hold over these alternative specifications.

\section{Summary and conclusion}

Noting that cross-border acquisitions are the most prominent form of FDI, this paper has focused on their determinants in the global food sector. To this end, we use data covering international acquisitions between 45 source and 46 host countries over the 1997-2004 period and encompassing over 2,000 merger deals. We are also able to split acquisition counts along the stages of the supply chain involving food production, processing (by far the most prominent sub-sector for international acquisitions), wholesaling and retailing. Drawing on recent developments in the literature on FDI, the results highlight a number of factors that are important in determining cross-border acquisitions, particularly market size, relative costs, trade costs and stock market growth. Interestingly, the factors that appear important in determining acquisitions vary according to the stage in the vertical chain. In addition, in terms of the geography of international acquisitions, the factors that drive cross-border acquisitions between high income (developed) countries differ from those that determine acquisitions involving lower income (developing) countries. Further exploitation of the data also suggests some differences in the factors determining acquisitions involving EU countries that adopted the Euro and those EU countries that did not.

FDI has emerged as the key feature of globalisation in recent years, the growth of FDI far-outstripping the growth of trade; yet there is comparatively little research in the agricultural economics literature on this issue. As such, while this paper exploits the key means of accessing foreign markets via FDI covering a large sample of countries, it does not endeavour to be the last word on this issue as there are a range of important research questions and policy questions that arise from the growth in FDI in the food sector. These include inter alia the effect of spillovers, technological transfers and trade policy among others. Observing that cross-border acquisitions are the key form of multinational access to host markets, understanding the potential factors that drive international acquisitions in the global food sector is an important issue to address. Moreover, in line with recent initiatives in the literature on trade and FDI, exploring the characteristics of individual firms who 
decide to invest overseas will be part of any future research agenda. In this context, the hope is that the present analysis makes a contribution towards this developing agenda.

\section{Acknowledgements}

We greatly appreciate the stimulating comments of the three referees and the advice of the coordinating editor, Thomas Heckelei, on previous versions of this paper.

\section{References}

Anastassopoulos, G. and Trail, B. (1998). Determinants of foreign entry strategies in the Greek food industry. Agribusiness 14: 267-279.

Barba-Navaretti, G. B. and Venables, A. J. (2004). Multinational Firms in the World Economy. Princeton and Oxford: Princeton University Press

Barkley, A. P. (2005). Multinational food corporations and trade: the impact of foreign direct investment on trade in the US food industry. In: R. Rama (ed.), Multinational Agribusiness. New York and London: Haworth Press Inc., 165-214.

Benito, G. R. G. (2000). Chain strategies and modes of foreign penetration in agribusiness. Journal of International Food and Agribusiness Marketing 11: 1-21.

Bernard, A. B., Jensen, J. B., Redding, S. J. and Schott, P. K. (2007). Firms in international trade. Journal of Economic Perspectives 21: 105-130.

Bertrand, O., Mucchielli, J. L. and Zitouna, H. (2004). Location Choice of Multinational Firms: The Case of Mergers and Acquisitions. Paris: University of Paris-Sorbonne.

Blonigen, B. (1997). Firm-specific assets and the link between exchange rates and foreign direct investment. American Economic Review 87: 447-465.

Blonigen, B. (2005). A review of the empirical literature on FDI determinants. NBER Working Paper 11299. Massachusetts.

Blonigen, B., Davies, R. B. and Head, K. (2003). Estimating the knowledge-capital model of the multinational enterprise: comment. American Economic Review 93: 980-994.

Blonigen, B., Davies, R. B., Waddell, G. R. and Naughton, H. T. (2007). FDI in space: spatial autoregressive relationships in foreign direct investment. European Economic Review 51: 1303-1325.

Braconier, H., Norbäck, P. J. and Urban, D. (2005). Multinational enterprises and wage costs: vertical FDI revisited. Journal of International Economics 67: 446-470.

Brakeman, S., Garretsen, H. and van Marrewijk, C. (2006). Cross-border mergers and acquisitions: the facts as a guide for international economics. CESIfo Working Paper no. 1823, Munich.

Cameron, A. C. and Trivedi, P. K. (1998). Regression Analysis of Count Data. Cambridge: Cambridge University Press.

Carr, D. L., Markusen, J. R. and Maskus, K. E. (2001). Estimating the knowledge capital model of the multinational enterprise. American Economic Review 91: 693-708.

Cho, G., Sheldon, I. M. and McCorriston, S. (2002). Exchange rate uncertainty and agricultural trade American Journal of Agricultural Economics 84: 931-942. 
Connor, J. M. (1983). Determinants of foreign direct investment by food and tobacco manufacturers. American Journal of Agricultural Economics 65: 395-404.

De Mooij, R. and Everdeen, S. (2003). Taxation and foreign direct investment: a synthesis of empirical research. International Tax and Public Finance 10: 673-696.

Di Giovanni, J. (2005). What drives capital flows? The case of cross-border M\&A activity and financial deepening. Journal of International Economics 65: 127-149.

Devereux, M. (2006). The impact of taxation on the location of capital, firms and profit: a survey of empirical evidence. University of Warwick, Institute of Fiscal Studies and Centre for Economic and Policy Research, Warwick.

Devereux, M. and Griffith, R. (1998). Taxes and the location of production: evidence from a panel of US multinationals. Journal of Public Economics 68: 335-367.

Djankov, S., La Porta, R., Lopez-de-Silanes, F. and Schleifer, A. (2002). The regulation of entry. Quarterly Journal of Economics 117: 1-37.

Evenett, S. (2003). The cross border mergers and acquisitions wave of the late 1990s. NBER Working Paper 9655. Massachusetts.

Feenstra, R. C. (1998). Integration of trade and disintegration of production in the global economy. Journal of Economic Perspectives 12: 31-50.

Froot, K. A. and Stein, J. C. (1991) Exchange rates and foreign direct investment: an imperfect capital markets approach. Quarterly Journal of Economics 106: 1191-1217.

Gopinath, M., Pick, D. and Vasavada, U. (1999). The economics of foreign direct investment and trade with an application to the US food processing industry. American Journal of Agricultural Economics 81: 442-453.

Guiletti, M., McCorriston, S. and Osborne, P. (2004). Foreign direct investment in the UK: evidence from a dis-aggregated panel of the UK food sector. Applied Economics 36: $653-663$.

Hijzen, A., Görg, H. and Manchin, M. (2008). Cross-border merger and acquisitions and the role of trade costs. European Economic Review 52: 849-866

Huizinga, H. and Voget, J. (2006). International taxation and the direction and volume of cross-border M\&As. CEPR Discussion Paper 5974. London.

Kessing, S., Konrad, K. and Kotsogiannis, C. (2007). Foreign direct investment and the dark side of decentralisation. Economic Policy 49: 5-70.

Klein, M. W. and Rosenberg, E. S. (1994). The real exchange rate and foreign direct investment in the United States: relative wealth vs. relative wage effects. Journal of International Economics 36: 373-389.

Markusen, J. R. (2002). Multinational Firms and the Theory of International Trade. Massachusetts: MIT Press.

Markusen, J. R. and Venables, A. J. (1998). Multinational firms and the new trade theory. Journal of International Economics 46: 183-203.

McCorriston, S. and Sheldon, I. M. (1998). Cross border acquisitions and foreign direct investment in the US food processing industry. American Journal of Agricultural Economics 80: 1066-1072.

Neary, P. (2007). Cross-border merger waves. Review of Economic Studies 74: 1229-1257. 
Ning, Y. and Reed, M. (1995). Locational determinants of the US foreign direct investment in food and kindred products. Agribusiness 11: 77-85.

Nocke, V. and Yeaple, S. (2007). Cross-border mergers and acquisitions vs. Greenfield foreign direct investment: the role of firm heterogeneity. Journal of International Economics 72: 336-365.

Portes, R. and Rey, H. (2005). The determinants of cross border equity flows. Journal of International Economics 65: 269-296.

Rossi, S. and Volpin, P. (2004). Cross-country determinants of mergers and acquisitions. Journal of Financial Economics 74: 277-304.

Tozanli, S. (2005). The rise of the global enterprise in the global food chain. In R. Rama (ed.) Multinational Agribusiness. New York and London: Haworth Press Inc.

UNCTAD (2001). World Investment Report 2000. United Nations Conference on Trade and Development, Geneva.

UNCTAD (2005). World Investment Report 2004. United Nations Conference on Trade and Development, Geneva.

Yeaple, S. R. (2003). The complex integration strategies of multinationals and cross country dependencies in the structure of foreign direct investment. Journal of International Economics 60: 293-314.

\section{Appendix 1: Country coverage}

The baseline specification of Table 4 employs data for the source countries reported in Table 3 as well as for the following host countries (e.g. where a domestic firm was a potential target of a cross-border acquisition over the sample period).

Australia, Austria, Belgium, Brazil, Canada, Chile, China, Colombia, Czech Republic, Estonia, Finland, France, Germany, Greece, Hungary, India, Indonesia, Ireland, Israel, Italy, Japan, Kenya, Korea, Latvia, Lithuania, Malaysia, Mexico, Nigeria, Netherlands, New Zealand, Norway, Pakistan, Panama, Peru, Philippines, Poland, Portugal, Singapore, Slovakia, South Africa, Spain, Sweden, Switzerland, Turkey, United Kingdom, United States.

\section{Appendix 2: Variable construction and data sources}

Corresponding author: Steve McCorriston, Department of Economics, University of Exeter Business School, Streatham Court, Exeter, Devon, UK EX4 4PU. E-mail: s.mccorriston@ex.ac.uk 
Table A1. Variables collected for 46 source countries and 51 host countries for the consecutive years between 1997 and 2004

\begin{tabular}{|c|c|c|c|}
\hline Variable & Unit & Description & Source \\
\hline \multicolumn{4}{|c|}{ Dependent variable } \\
\hline$C B A_{i j, t}$ & Count & $\begin{array}{l}\text { Number of international merger deals between source and host } \\
\text { countries for each year. Based on Standard Industry Classification } \\
\text { (SIC) codes, CBA activity has also been counted for the entire food } \\
\text { industry, food production (SIC 01, 02, 07), food processing (SIC } \\
\text { 20), food wholesaling (SIC 5141-5154) and retailing (SIC 54). }\end{array}$ & $\begin{array}{l}\text { Compiled from SDC Platinum of } \\
\text { Thomson Financial. }\end{array}$ \\
\hline \multicolumn{4}{|c|}{ Independent variables } \\
\hline$g d p_{i, t} * g d p_{j, t}$ & Billion US\$ & $\begin{array}{l}\text { Real Gross Domestic Product denominated in US\$ with base year } \\
2000 \text { in terms of logarithmic product between source and host } \\
\text { country. }\end{array}$ & $\begin{array}{l}\text { World Development Indicators } \\
\text { (WDI). }\end{array}$ \\
\hline$\Delta$ wage $_{i j, t}$ & Index $($ Zurich $=100)$ & $\begin{array}{l}\text { Logarithmic wage difference between source and host country. Wages } \\
\text { are measured by an index referring to the hourly income of } 13 \\
\text { comparable professions (product managers, department heads, } \\
\text { engineers, primary school teachers, bus drivers, car mechanics, } \\
\text { building labourers, industrial workers, cooks, bank credit officers, } \\
\text { personal assistants, sales assistants, factory workers) as paid in the } \\
\text { capital city or the financial centre of a country. Data are published } \\
\text { on a tri-annual basis. Values of the (missing) years 1998, 2002, } \\
1999 \text { and } 2001 \text { have been matched with the observations of the year } \\
\text { 1997, } 2003 \text { and 2000, respectively. }\end{array}$ & UBS, Prices and Earnings. \\
\hline
\end{tabular}


distance $_{i j}$

1000 kilometres

$\begin{array}{ll}L A N G U A G E_{i j} & \text { Indicator } \\ C U_{i j, t} & \text { Indicator } \\ \operatorname{taxdiff}_{j i, t} & \text { Per cent }\end{array}$

entrycost $_{j, t}$

Per cent of GDP per capita

propright $_{j, t}$ Index score

$\begin{array}{ll}\text { stock }_{i, t} & \text { Per cent } \\ \text { stock }_{j, t} & \text { Per cent } \\ \text { exrate }_{i j, t} & \text { Ratio }\end{array}$

Great circular distance between capital cities of source and host country.

Indicator variable identifying a common official language between host and source country.

Indicator variable identifying a customs union between source and host country.

Difference in top marginal corporate tax rate between host and source country levied at the national level of government between source and host country

Regulatory burden of doing business and investment in terms of relative cost involved to legally set up a business.

Rating of property rights in host country. Original values have been reversed on a scale from 1 to 5 such that higher values indicate more secure property rights.

Average capitalisation of the stock market as percent of GDP of the source country.

Average capitalisation of the stock market as percent of GDP of the host country.

Real exchange rate in terms of price conversion factor multiplied with the nominal exchange rate. An increase implies a real appreciation.
Compiled from US Department of Agriculture

(www.wcrl.ars.usda.gov/cec/ java/capitals.htm).

Compiled from CIA World

Factbook.

Compiled from WTO.

University of Michigan (years 1997-2002) and Institute for Fiscal Studies (years 20032004).

Djankov et al. (2002) and World Bank.

Heritage Foundation.

Compiled from WDI.

Compiled from WDI.

Compiled from WDI.

Note: The first and second columns give the name and the unit of the variable, respectively. The third and fourth columns describe the variable and provide the sources, from which it was collected. 